\title{
Beyond Global vs. Local: Economic Politics Outside the Binary Frame
}

\author{
J. K. Gibson-Graham
}

\section{Rumination 1}

Recently we gave a talk at a US university on "Imagining and Enacting Noncapitalist Futures" - a discussion of our action research projects in the Pioneer Valley of New England, USA and the Latrobe Valley of SE Australia. We were aware of a senior Marxist geographer sitting in the back row, listening attentively. Near the end of the question and answer period, after some urging, he made his intervention. Our material was interesting, he said, but it wasn't compelling. We failed to acknowledge the power of global economic dynamics and the force of political conservatism that could squash alternative economic experiments of the kind we had described. We seemed oblivious to the many historical examples of local endeavors that had ended in disbandment, defeat, and disgrace.

Cast, yet again, as the Pollyannas of the profession, we initially accepted this cold blast of "realism" as a sobering footnote to our presentation about imagining and becoming. But in retrospect we are less willing to allow this belittling reaction to stand unchallenged. Where, we ask ourselves, does the desire to speak the power of global forces originate? Why was this person's global perspective, his "everything dealt with" analysis, so convincing to others in the room? ${ }^{1}$ And why did so many young people in the audience want to retain a critical or even cynical stance and to accept his view that the forces of globalization were inevitably more powerful than progressive, grassroots, local interventions? 


\section{Rumination 2}

After a presentation at an Australian university where we talked about the work of ENGENDER, a Singapore-based NGO engaged in alternative livelihood projects with women in South East Asia, an incredulous Pacific historian derided us: "Do you really think that by earning $\$ 1,000$ a year from selling village craft goods to international tourist resorts, rural Indonesian households will be able to prevent their daughters from being exploited in the Nike factory across the Straits?"

This response resonated with that of our disciplinary master. The historian appeared to scorn the hopefulness attached to the telling of small stories at the local level. Indeed, he was offended by the airspace we devote to such material. "Why waste the time of serious people with such trivia?" he seemed to say.

\section{Rumination 3}

On many occasions we have used the story of Mondragon to illustrate the possibilities and potentialities of local experiments. The Mondragon Co-operative Corporation (MCC) is a complex of industrial co-operatives in the Basque region of Spain that is famed for its almost 40,000 workers, as well as its successes in international markets and the panoply of service sector co-ops (in addition to the industrial co-ops) that provide banking, venture capital, research and development, and educational, health, and retailing services to co-op members and others. On one occasion, a senior industrial geographer came up to discuss the Mondragon case with us after a presentation that had focused largely upon our own community-based action research. Our friend was clearly relieved that we had made mention of Mondragon, a noncapitalist organization that was large and impressive, compared to the small-scale experiments that seemed - according to a cultural geographer in the audience - like "old-style, feel-good community development." Moreover, it was clear that the MCC's recent foray out of the Basque region to set up factories in international locations (North Africa, Europe, and Thailand) was somehow reassuring to this progressive and committed individual. That the MCC appeared to be "upscaling" just like capitalist multinationals was a cause for celebration. Had the very successful network of co-operatives remained local, regional, or even national, their power would have been questionable in his eyes.

Why, we have begun to wonder, do local projects stimulate these kinds of reactions? In all of them, as in our own responses, we recognize something visceral. The disavowal or denunciation of attempts 
to elaborate a localized economic politics seems to emanate from a bodily state, not simply a reasoned intellectual position. For many, it seems, recourse to the obviousness of global power provides a form of comfort, one that we find difficult to replicate or displace.

\section{Familiarity Breeds Contempt: The Local Versus the Global}

We are all familiar with the denigration of the local as small and relatively powerless, defined and confined by the global: the global is a force, the local is its field of play; the global is penetrating, the local penetrated and transformed. Globalism is synonymous with abstract space, the frictionless movement of money and commodities, the expansiveness and inventiveness of capitalism and the market. But its Other, localism, is coded as place, community, defensiveness, bounded identity, in situ labor, noncapitalism, the traditional. ${ }^{2}$

Of course, in such a representation localities are not passive, or not entirely so. They interact in the process of transformation, creating a heterogeneous landscape of globalization - but somehow global dominance is untransformed in the interaction. Thus, it is the global that appears as a telos on the move in the ongoing process called "globalization." The association of globalization with capital lends energy to the global and compounds the subordination of the local. Not only are localities subsumed as interior to the global, but noncapitalist economic activities involving households, collectives, independent producers, barter networks, etc. - all ostensibly local - are seen as contained and ultimately dominated by a global capitalist economy.

For instance, in their depictions of "geographical rescaling," writers such as Erik Swyngedouw, Neil Smith, and David Harvey invoke the association between capital, power, and the global. Thus Swyngedouw (1997: 170, inserts ours) argues that:

Changes in scales of production/reproduction can go either upwards or downwards, but will always express new power relations and shift the balance more to one side than another. Over the past decades, it has been mainly capital that "jumped" upwards [to the global scale], while in many cases (and with varying degrees of resistance) the regulation of labor moved downwards [to the local scale].

Upscaling (globalization) seems to be the prerogative of capital and downscaling (localization) the forced option for labor. According to 
Smith (1993) and Swyngedouw (1997), then, the new "gestalt of scale" is one in which the global is appropriating more power. ${ }^{3}$ Add to this Harvey and Swyngedouw's (1993) assessment that

oppositional groups, whether organized around working-class, gender, environmental or other politics, are usually much better and empowering in their strategies to organize in place, but often disempowered and fragmented when it comes to building alliances and organizing collaboration over space. (quoted in Swyngedouw 1997: 176)

In their view globalization ("the global control of money flows and competitive whirlwinds of 'glocal' industrial, financial, cultural and political corporations and institutions") requires that local struggles be conducted on a larger scale, using "co-ordinated action, crossspatial alliances and effective solidarity" (Swyngedouw 1997: 176).

However, Harvey, Swyngedouw, and Smith seem captured by the vision that power inheres in greater size and spatial extensiveness and that real opposition must involve formal interplace organization. ${ }^{4}$ The limits of large entities (including the manifold failures of MNCs and large nation-states to enact their will) and the effectivity of small ones (chaos theory's affirmation of the saying that a butterfly flapping its wings can affect the weather half a world away) are not sufficient to dislodge their belief in the boundless power of the global and the relative impotence of the local. Their interest in globalization is to understand it, expose it, and, hopefully, transform it, but they are not attracted to the local as a site of realistic challenge and possibility. ${ }^{5}$

In the book Empire (which is their name for the emerging global form of governance/subjection), Michael Hardt and Antonio Negri (2000: 206) concur with this vision of the appropriate scale for an oppositional politics:

We believe that toward the end of challenging and resisting Empire and its world market, it is necessary to pose any alternative at an equally global level. Any proposition of a particular community in isolation, defined in racial, religious, or regional terms, "delinked" from Empire, shielded from its powers by fixed boundaries, is destined to end up as a kind of ghetto. Empire cannot be resisted by a project aimed at a limited, local autonomy.

Place-based politics and the localization of struggles are denigrated by them (2000: 45$)$ as inherently regressive:

This Leftist strategy of resistance to globalization and defense of locality is also damaging because in many cases what appear as local 
identities are not autonomous or self-determining but actually feed into and support the development of the capitalist imperial machine. The globalization and deterritorialization operated by the imperial machine is not in fact opposed to localization or reterritorialization, but rather sets in play mobile and modulating circuits of differentiation and identification. The strategy of local resistance misidentifies and thus masks the enemy.

It is not, then, that local struggles are insufficiently powerful to counter global forces, in Hardt and Negri's view, but that local struggles actually cede power to an expansive capitalism by fragmenting the "global multitude" and blinding them to the "real alternative and the potentials for liberation that exist within Empire" (2000: 46). Unless resistance operates in certain global ways, it is tainted and reactionary. Local activism, when it involves defense of locality, invites forms of identification that privilege differentiation. Supported by postmodern theory, this kind of politics merely yokes uniqueness into a hegemonic power field - Empire. ${ }^{6}$

\section{Rumination 4}

In our related action research projects in different parts of the world we have employed a vision of diverse community economies as a way of conversing about alternative development pathways that do not conform to the new global (capitalist) "order." We are eager not to have these projects sequestered in a second-class domain - seen as worthy and interesting, perhaps, but as failing to challenge the power of global forces. Yet our language repeatedly exposes us to familiar difficulties and dangers. "Community" is often associated with place, with the local, and also with the confined and constrained. And "diversity" conjures images of a fragmentary politics of identity - the very enemy of the "collective resistance" that is the only hope of many antiglobalization theorists. We are treading on treacherous ground here, fractured by the fault line of global versus local.

Perhaps it is the power differential embedded in the binaries of global and local, space and place, that is responsible for the hostile or incredulous responses we receive (and indeed we do try to receive rather than simply to repel them). As with any such binary formulation within Western knowledge systems, superior power is already distributed to the primary or master term. Inevitably, then, projects of valuing the subordinate term come up against the always alreadyunequal allocation. Given this condition, local stories are patently ridiculous as ammunition for challenging the dominance and power of the global. 
But since the local is the space of politics for most economic activists, it seems that we need to question its positioning as interior to the global and as a second best (or worse) political terrain. This repositioning of the local has already been done any number of times - but in the so-called era of globalization it is continually being undone and needs to be done again.

\section{Challenging the Global/Local Binary}

We have identified two strategies for challenging the power of the global/local binary. The first involves the tools of deconstruction, the theoretical intervention that has been so effective in shaking loose static identities that constrain thought and politics (Gibson-Graham 2000). The other involves practices of resubjectivation, a set of embodied interventions that attempt to confront and reshape the ways in which we live and enact the power of the global. While the former strategy is the more familiar, the latter seems to us more likely to be efficacious, since it addresses the deep affective substrate of our subjection to globalization.

Turning first to the resources of deconstruction, we find "global" and "local" positioned in a familiar hierarchy wherein each derives meaning from the other. The global is represented as sufficient, whole, powerful, and transformative in relation to which the local is deficient, fragmented, weak, and acted upon. Critics have attempted to destabilize this identity structure in a number of ways. In surveying this well-trodden critical ground yet again, we have resorted to a set of annotated signposts, dividing the challenges into those that see global and local as different "perspectives," those that see them as somehow "the same," and those that see both sides of the binary as referring to specific processes that are always in motion. (Like all distinctions, this categorization enhances visibility but disintegrates upon inspection.)

\section{Perspectives}

1. The global and the local are not things in themselves, nor are "globalness" and "localness" inherent qualities of an object. They are interpretive frames - scales of analysis, for example (GibsonGraham 1999a).

One way to loosen the differential hold of the global and the local is to see them both as scales of analysis or interpretive frames, inherently 
empty of content. This move opposes the tendency to objectify both local and global, to perceive "localness" or "globalness" as essential or real qualities of an object. But does this really help us? As soon as we talk of scales of analysis we must distinguish between "different" scales. As geographers we are taught that at the global (technically, the "small") scale geographic details are sacrificed for broad patterns of differentiation and homogeneity. And at the local (or "large") scale broad patterns may not be visible but fine details can be registered. Thus, a higher "level of abstraction" is attached to the more extensive scalar view and concreteness is associated with the more limited scalar perspective. Already, differential valuations are entailed. Deep in our epistemic bones we prefer abstraction to concreteness and are ready to give more power to general and extensive processes than to specific and intensive ones. Western Enlightenment thought tempts us to attach meaning to otherwise "empty" scales of analysis and the global comes out a winner again.

2. The global and the local each derive meaning from what they are not. The global is "something more than the national or regional... anything other than the local," and while the local once "derived its meaning from its contradiction to the national," now "nations and entire extra-national regions may qualify as references for the local" (Dirlik 1999: 4).

This is a familiar deconstructive move highlighting the dependence of each term on the other (thus rendering the master term no longer sufficient and complete). Yet this move is readily subverted. Dirlik points to the historical shift in the meaning of the local, such that now whole national groupings can, in relation to the global, be seen as "local." What is defined as "other than the local" appears to be setting the agenda for what constitutes the local, rendering larger and larger entities "small." The original binary is reinstated with the global conceptualized in a grander (and therefore more powerful) way.

3. Local and global "offer points of view on networks that are by nature neither local or global, but are more or less long and more or less connected" (Latour 1993: 122).

The global and local are but different "takes" on the same universe of networks, connections, abstractness, and concreteness. Are they, though, merely different ways of focusing on this universe, or do they have a content that is specific to themselves? Shorter and 
less connected versus longer and more connected networks imply a concrete difference that resonates with conceptions of power differentials. Greater size and extensiveness imply domination and superior power in our Western discursive universe. How can we not see global networks as enrolling and enlisting more power than local ones?

\section{The same}

1. The global is local, in that it refers to processes that touch only certain (local) parts of the globe.

The global does not exist, or at least not in any stable and generic relation to other scales. Scratch anything "global" and you find locality - grounded practices in factories, stock exchanges, retail outlets, and communities. The contemporary formation of regional trading blocs is a process of regionalization and regulation, rather than one of unfettered globalization and deregulation, while multinational firms are actually multilocal rather than global, though the statistics on their profits and internal and external transactions are used as indicators of globalization.

2. The local is global, and place is a "particular moment" in spatialized networks of social relations. The uniqueness of place is not defined only by what is "included within that place itself" but "includes relations which stretch beyond - the global as part of what constitutes the local" (Massey 1994: 5).

The suggestion that place be seen as a "particular moment" in a set of relations whose uniqueness is given by the concrete specificity of interconnections highlights the overdetermination of a particular site. Here, the local or place is not a thing but a way of seeing and focusing - an "entry point," if you like.

\section{Processes}

The global and local are processes, not locations. Globalization and localization produce all spaces as hybrids, as "glocal" sites of both differentiation and integration (Dirlik 1999: 20).

The local and the global are not fixed entities but are contingently produced, always in the process of being re-produced and never 
completed. Thus, places contain processes that can be globalized. Local initiatives can be broadcast to the world and adopted in multiple places across space - the Grameen bank, for instance, is replicated in countless low-income neighborhoods across the world. And global processes always involve localization - the arrival of the McDonald's outlet on the next block, the local link-up to cable TV, the building of a factory on customary-owned land. This focus upon process opens up the binary to politics, to interventions that can interact to change the nature of globalization and localization (Escobar 2001).

From this brief foray into current deconstructive analyses, it is clear that global and local are recognized as existing within a structured formation that differentially distributes power to one term. Challenges to the global/local binary attempt to break down the dualist structure of difference, allowing us to see that the global is not global, the local is not local, and the local is not powerless or even less powerful. They argue for the unfixity and multiple meanings attached to each term, and resituate them as processes whose courses are unknown and potentially malleable. ${ }^{7}$ The recognition that the differential positioning of the global with respect to the local emerges from the discourse of globalization, and that this discourse is produced and purveyed by theorists, becomes the starting point for a politics outside the binary frame.

What emerges from this abbreviated review of attempts to destabilize the global/local binary, however, is an overriding sense that the power differential is never completely eradicated by deconstructive reason and re-presentation. Power, it seems, is either already distributed and possessed or able to be mobilized more successfully by "the global" (whatever that may be). The efforts to render global and local as somehow the "same" end up allowing the global to retain its power, and the representational shift associated with seeing the local and the global as processes, as always unfixed, is curiously circumscribed by a sense of imbalance. Dirlik (1999: 42, italics ours), for example, in his discussion of the glocal, notes that "most phenomena are both global and local, but they are not all local and global in the same way." Does not the italicized phrase create an opening for unequal power to be reinserted?

Arif Dirlik's work has prompted us to push a little at this point as we find it both appealing and disturbing. ${ }^{8}$ Like many others interested in destabilizing the hegemony of capitalist globalization, Dirlik is interested in place as a political project. He sees (2001: 15) "the 
struggle for place in the concrete [as] a struggle against power, and the hegemony of abstraction." Conversely, the global project is a struggle in the concrete for power and the "essential placelessness of capitalism" (2001: 16). But having done so much to argue for a politics of place "in the face of globalization," he is ultimately convinced that "the globalization of the local does not compensate in terms of politics, economy and culture for the localization of the global" (1999: 42). ${ }^{9}$ In the enactment of globalization and localization there is inevitably an unequal exchange of power - the one does not compensate fully for the other:

What appears today as something of an exchange, in which both sides participate, may turn out to be less of an exchange because it is unequal exchange, because one side will see its life transformed by television while the other side will through the same television invade the world and create a new structural context for its operations. (Dirlik 1999: 42)

Along with Escobar (2001), Dirlik argues (1999: 45) that the political primacy and autonomy of place is the "irreducible basis" upon which to "produce translocal or, better still, transplace alliances and co-operative formations" - what others have called "grassroots globalization" or "globalization from below."10 Drawing upon the vision of power as the capacity to mobilize across space (Allen 1999), he believes that the local networks of place-based politics must be developed at the same (global) scale if they are to offer effective resistance to global forces. Despite his intentions and different starting point, Dirlik ends up sounding not unlike Harvey or, for that matter, Hardt and Negri. ${ }^{11}$ If even the most ardent advocates of place as a ground of politics fall back into agreement with the imperative to "upscale," where is the space of hope and effectivity for those of us who wish to enact a local economic politics?

\section{Subjection to Globalization}

Whether they present their analyses as truths requiring certain actions or as deconstructive arguments that challenge a discourse for political ends, it seems that most theorists do not see themselves as powerfully constituted by globalization. The realists see the world as taken over by global capitalism, the new Empire. The deconstructionists see a dominant discourse of globalization that is setting the political and policy agenda. In different ways they both stand outside 
globalization and "see it as it is" - yet the power of globalization seems to have colonized their political imaginations.

Judith Butler (1997: 11) notes the deep complicity between power and its subjects:

A power exerted on a subject, subjection is nevertheless a power assumed by the subject, an assumption that constitutes the instrument of that subject's becoming.

Is it possible that the power of globalization (obvious to many as having taken over either the world or discourse) has also taken over the bodies of its critics? Could this affective subjection exerted on/ assumed by the intellectual and activist be standing in the way of elaborating a politics beyond the binary frame? These questions have begun to tease our (self)reflection.

We are very much drawn to the idea of place as a political project (despite the cautionary and condescending language of Hardt and Negri). At this moment, when power is ceded to globalization by all and sundry, it seems both timely and important to reshape the effectivity of the local (Gibson-Graham 2003). But what does "politics" involve in a local context? Must local struggle emulate global institutions and forces, as so many assert, in order to be powerful and effective ${ }^{12}$ Is the defense of locality or place-based struggle necessarily more regressive or reactive than the championing of globally networked initiatives?

As feminists, we are reminded of the incredible power of discussions around kitchen tables and village wells that formed much of the political practice of a women's "movement" of global proportions. It is important not to underestimate the magnitude and extent of this movement. It transformed and continues to transform households, lives, and livelihoods around the world to different degrees and in different ways, rendering the life experiences of many women literally unrecognizable in the terms of a generation ago. ${ }^{13}$ The "upscaling" or globalization of a feminist politics did not necessarily involve formal organization, coordinated actions, and alliances (although some of these followed upon the "second wave"). Indeed, the movement has remained largely discursive, often personal, unor under-resourced. Perhaps it is the continually revitalizing and transformative energy of this relatively unorganized movement that encourages us to pursue a different kind of politics, outside the global/local binary.

We are enticed to think not about how the world is subjected to globalization (and the global capitalist economy) but how we are 
subjected to the discourse of globalization and the identities (and narratives) it dictates for us. In The End of Capitalism (As We Knew It), we gained insight into how economic subjects might be subjected within globalization discourse by examining the work of Sharon Marcus on rape. Marcus (1992) points to the important role of language, narrative, and discursive constructions of sexual identity in circumscribing women's ability to act powerfully during the rape event. This resonated for us with the limited options for economic identity and power offered to local subjects by a capitalocentric discourse of globalization. ${ }^{14}$ We likened freeing ourselves from the discourse of globalization to women shaking away their embodied self-understanding as always already victimized within the discourse of rape.

It seems to us that a politics of the local (an antiglobalization politics that is not simply "grassroots globalization") will go nowhere without subjects who can experience themselves as free from capitalist globalization. Our project of revaluing the local as a site of politics is not about "liberation" from subjection as such, but about creating new discourses that subject in different ways, thus enabling subjects to assume power in new forms. ${ }^{15}$ Liberating the subject from the economic identities provided by the discourse of globalization requires creating alternative economic identities that subjects can take on (Gibson-Graham 1994).

Ultimately, then, the political project is one of resubjectivation, a process that is both prior to, and concomitant with, the building of alternative economic institutions and practices. Our strategies for resubjectivation involve two major steps. The first involves creating a discourse of the diverse economy, where noncapitalist activities are visible and viable in the economic terrain. The second engages in the micropolitics of enabling subjects to inhabit that terrain - taking on novel economic identities within a diverse economy and assuming the powers these new identities bestow.

\section{Resubjectivation 1: Creating a New Symbolic - A Discourse of the Diverse Economy}

In seeking to represent economic difference, we have come up against the poverty of economic language, which avails us few concepts with which to describe economic diversity and few resources for interpellating alternative economic subjects. The paucity of language is particularly problematic if we understand economic discourse as performative, producing rather than reflecting the reality it describes. Echoing Latour on performativity, Michel Callon (1998: 2) 
argues that "economics, in the broad sense of the term, performs, shapes, and formats the economy, rather than observing how it functions." If, then, the economy could be represented as diverse and decentered, and this representation were widely accepted, the power of capitalist globalization (with all the unidirectionality, domination, and singularity it implies) could be dispersed and redefined. New economic subjects could emerge, ones not subjected to a capitalist economy as workers, entrepreneurs, investors, and the unemployed.

Creating a discourse of economic difference in which the economy is diverse (rather than primarily capitalist) and in which economic dynamics are multiple (rather than limited to the quest for profitability and the law of the market) and overdetermined (rather than naturally dominant) (Graham 1992) is not a task we take on lightly. There is no readily available language with which to represent the variety of production relations, transactions, markets, property and other relations and practices that make up our economic world. Take the market, for example, the mechanism that is most often seen as producing globalization and the victimization of the local. Altvater (1993: 80-1) has this to say:

When "the market" is invoked today, nearly fifty years after the construction of the postwar order, the main referent must be to the world market - to the markets for goods and services, capital (or "loci of production"), money and credit. The world market is the site of economic reproduction of the global capital relation, as well as of the political organization of hegemony. An opening to the world market is thus synonymous with integration into the global process of economic reproduction and a historically determined system of hegemony.

Hardt and Negri (2000: 190) harmonize on the same theme, arguing that

the capitalist market is one machine that has always run counter to any division between inside and outside. It is thwarted by barriers and exclusions; it thrives instead by including always more within its sphere. Profit can be generated only through contact, engagement, interchange, and commerce. The realization of the world market would constitute the point of arrival of this tendency. In its ideal form there is no outside to the world market: the entire globe is its domain ...the world market might serve adequately....as the diagram of imperial power.

Kevin Danaher (2001: 12) makes a related argument: 
top-down globalisation is characterised by a constant drive to maximise profits for globe-spanning corporations. It forces countries to "open up" their national economies to large corporations, reduce social services, privatise state functions, deregulate the economy, be "efficient" and competitive, and submit everything and everyone to the rule of "market forces." Because markets move resources only in the direction of those with money, social inequality has reached grotesque levels.

These representations portray the market as singular, mysterious, normal, lawful, imbued with expansive authority and force. Yet, as we examine the diversity of markets and ways in which individuals and enterprises of any form (co-operatives, small businesses, capitalist businesses, feudal enterprises, etc.) interact with markets, we see how they are constructed, protected, played with, manipulated, bounded, undermined, institutionalized, deinstitutionalized, personalized, niched, and so on. Can we talk of the market? Only if we are willing to obscure these differences. Not all markets are for capitalist commodities, nor are they all naturally expansive or dominant. ${ }^{16}$ Yet where is our language to express market dynamics differently? And what about the non-market economic transactions that are also key to our economy, such as gifts, in-kind exchanges, barter, internal transactions within enterprises, and contracted payments? What of the multiple noncapitalist ways in which surplus labor is produced, appropriated, and distributed within the different kinds of economic organizations that produce and purvey goods and services?

It is clear that economic literacy is dominated by the singularity of capitalist production, wage labor, and "the" capitalist market. Yet, when we think of the immense variety of ways in which goods and services are produced and transacted in society, these economic identities and sites are but the paltry tip of a complex iceberg.

In figure 1.1 we have sketched out how we have begun to think of the "diverse economy" in terms of multiple types of transactions, forms of labor, and ways of organizing surplus production and appropriation. The right-hand column on forms of organization is inspired by Marx's distinction between capitalist and various noncapitalist forms of surplus appropriation and distribution. As Marx was primarily interested in the rise of capitalist class relations, most of his discussion in Capital explores the way in which surplus labor (in value form) produced by workers is appropriated by the capitalist (or board of directors of a capitalist firm) and distributed through a variety of payments (including interest payments, rent, taxes, management salaries, and dividends, as well as payments to the capitalist's 
accumulation fund). He did, however, also describe noncapitalist class processes (for example, feudal, slave, independent or individual, and communal or communist) where the production, appropriation, and distribution of surplus is differently arranged. Whereas in an independent class process, for example, an individual produces, appropriates, and distributes her own surplus, in a communal class process the producers jointly decide what should be considered necessary and surplus labor, and they are the appropriators and first distributors of surplus (Gibson-Graham et al. 2000, 2001).

\begin{tabular}{|c|c|c|}
\hline Transactions & Labor & Organizational form \\
\hline MARKET & WAGE & CAPITALIST \\
\hline $\begin{array}{c}\text { ALTERNATIVE } \\
\text { MARKET }\end{array}$ & $\begin{array}{c}\text { ALTERNATIVE } \\
\text { PAID }\end{array}$ & $\begin{array}{c}\text { ALTERNATIVE } \\
\text { CAPITALIST }\end{array}$ \\
\hline $\begin{array}{c}\text { Local trading systems } \\
\text { Alternative currencies } \\
\text { Black market }\end{array}$ & $\begin{array}{l}\text { Co-operative } \\
\text { Self-employed } \\
\text { Indentured }\end{array}$ & $\begin{array}{l}\text { Environmental ethic } \\
\text { Social ethic }\end{array}$ \\
\hline NONMARKET & UNPAID & NONCAPITALIST \\
\hline $\begin{array}{c}\text { Barter } \\
\text { Household flows } \\
\text { Gifts }\end{array}$ & $\begin{array}{l}\text { Volunteer } \\
\text { Housework } \\
\text { Family care }\end{array}$ & $\begin{array}{l}\text { Communal } \\
\text { Independent } \\
\text { Feudal } \\
\text { Slave }\end{array}$ \\
\hline
\end{tabular}

Figure 1.1 A diverse economy

When we begin to use this rudimentary language of class and organizational difference, the economic landscape is suddenly transformed. A huge sector of noncapitalist economic activity in households, voluntary organizations, "third world" countries, cooperatives, prisons, small businesses, and communities looms large on the economic horizon and we can begin to question the superiority of global capitalism in terms of its size and extensiveness. The voices of noncapitalist practices begin to be heard in an intelligible tongue - one perhaps recognized by economic development practitioners or feminist economists or theorists of the informal sector. No longer represented in the language of community service, household arrangements, welfare, voluntarism, or black economies, the multifarious practices of the diverse economy can be re-cognized in a new 
language of economy. A discourse of economic difference begins to emerge.

The aim of reading the landscape for economic difference is not only to highlight all those "silent" or "invisible" sites and forms of labor whose effectivity in "the economy" are usually ignored, but also to show how these forms of labor interact with, and produce alongside, wage labor and capitalist production. This brings to the foreground the interdependence of "capitalist" and diverse "noncapitalist" economic practices. For us, one effect of representing the economy as multiply identified and complexly overdetermined is to open up the possibility that "local" noncapitalist economic practices "matter" (and can be seen, for example, as crucial "drivers" of development) and should therefore be a focus of an invigorated economic politics. ${ }^{17}$

Another effect of this representation is to allow a more sympathetic and empowered reading of already-existing examples of what we call "intentional economies" - communities and enterprises that have been explicitly developed as noncapitalist sites in which people are actively subjected to different discourses of economy. ${ }^{18} \mathrm{~A}$ discourse of the diverse economy emboldens a noncapitalocentric reading of intentional economies and helps us to unravel the ways in which strategic interventions in markets, production, and property relations have successfully created local subjects who are not interpellated by capitalist globalization. Thus, the Mondragon cooperatives thrive because there is no lack of subjects who are committed to supporting this alternative economic development pathway. But these subjects did not arrive on the scene, ready-made. They have been created through a long history of interconnected cultural and social practices, including Basque language maintenance and schooling in co-operative principles. ${ }^{19}$ Throughout its history, the Mondragon movement has been aware of the need to produce subjects who could assume the "subjection" of co-operativism. Our challenge is to get our language of economic diversity to do the same.

\section{Resubjectivation 2: Enabling Identification - The Micropolitics of Subjection within a Diverse Economy}

It is not enough to say that the subject is constituted in a symbolic system. It is not just in the play of symbols that the subject is constituted. It is constituted in real practices - historically analyzable practices. There is a technology of the constitution of the self which cuts across symbolic systems while using them. (Foucault 1984: 369) 
Our action research projects work in what might be called the underdetermined terrain of the noncapitalist economy (Sharp 2000). ${ }^{20}$ The language project outlined above is a strategic attempt to create a new symbolic field where economic practices might be re-presented in an anticapitalocentric way. This is an intervention to perform the prevalence, or perhaps even dominance, of diverse noncapitalist activities within an economy usually represented as hegemonically "capitalist." But this intervention cannot by itself create subjects of the diverse economy - people who can assume identity and agency via their subjection within a new symbolic system. A major challenge in our projects has been to engender novel identifications among potential subjects of "noncapitalist development."

We have employed a number of different strategies to release subjects from the body-snatching grip of globalization discourse. Not all have relied upon argumentation and exemplification. Indeed, we have become increasingly aware of the importance of cultivating a visceral receptivity to new becomings as a way of empowering local projects of alternative development. ${ }^{21}$ One strategy has been to create conversational spaces where groups experience the affective power of re-cognition as well-known practices are re-presented as alternative economic activities. Another has been to engage community members in learning the language of economic difference and creating opportunities to practice speaking it in supportive contexts, encouraging this language to enter into the unconscious where it can unleash dreams, fantasies, and projections. A third has been to involve people in projects and working groups in the community economy. ${ }^{22}$

\section{Creating space for identification}

As part of one project we conducted focus groups in a rural agricultural region (Shepparton) and a resource-based region (Latrobe Valley) in southeast Australia. Participants explored the social and economic impacts of the past 15-20 years of economic restructuring involving capitalization and growth in Shepparton and disinvestment and decline in the Latrobe Valley (Gibson et al. 1999). In both contexts the locality was represented as acted upon by global and national forces beyond its control and the community was seen as having to "cope." The mood of the group was respectful and relatively subdued as various stories and analyses were aired, broken only by occasional eruptions of emotion.

But when participants were asked to think of stories of success and hope in their regions, we observed a palpable shift in mood, an 
acceleration of pace, and heightened excitement - no matter that the responses were halting and disorganized, with no obvious narrative structure to follow. As each example was related, other stories came to mind, yielding ever more varied interpretations of "success." Among the many examples mentioned were: a voluntary community jazz club; The Bridge, a youth drop-in center; Dasma, a garbage recycling business that employs people who are intellectually disabled; an antisalinity community drains project; the Rumbalara Football and Netball sporting club for indigenous Australians; and WoodWorx, a woodworking concern run by unemployed workers using recycled timber donated by "local" multinational corporate actors (Gibson et al. 1999: 30-3). All were instances of economic and social enterprises within the noncapitalist or alternative capitalist sectors. All were potential sites of new forms of subjectivation. And all were projects that cultivated the local subject, allowing people to become subjects rather than objects of development.

The changed mood and disposition of bodies that accompanied this creative and imaginative exercise prompted us to organize another event in which the examples they had mentioned (and others) could be showcased and re-presented as elements of a diverse economy. We were eager to build upon the receptivity to "thinking otherwise" that had emerged in the focus groups and to harness it in a number of ways. In particular, we were interested in intervening in the political debate that had recently erupted over the "crisis" of the bush. Rural and regional Australia was portrayed in the popular media as an economic and social disaster area and in this context a new political party ("One Nation," led by Pauline Hanson) had emerged to mobilize economic nationalist, anti-immigration, and racist sentiments within the Australian electorate. A notable effect had been the acceleration of regional competition for new capital investment and government handouts that policy-makers in each place hoped would pull the regions out of "crisis." It seemed important to create a space where new becomings might be fostered that could counter this reactive and self-interested politics of place.

Using the video facilities of regional universities in three eastern Australian states (Queensland, New South Wales, and Victoria) we organized a video conference in which community spokespeople from eleven organizations spoke for ten minutes each about their history and activities (Gibson-Graham 1999b; www.communityeconomies.org/projects/videoconf.html). The audience in each location consisted of activists, community members, and academics. After watching the presentations, the assembled group at each university 
broke into small groups to discuss the cases and what could be learned from them.

The projects prioritized social and environmental values over profits, mobilized the untapped and undervalued resources of the community, and built partnerships across a variety of differences. For example, an organizer of Home Paddock, a co-operative association of independent farm-based food and home crafts producers, explained how, by collectivizing their marketing efforts and occupational health and safety training and certification, a group of selfemployed rural women were able to generate extra-farm income to enable their families to stay on the land. A self-named "jack-of-alltrades" told the story of WoodWorx, highlighting the growing interdependence between the local logging and paper manufacturing multinational and a group of retrenched electricity workers and unemployed youth who have gained access to the unwanted timber on company land. With a portable saw mill, they process the timber on site and then make beautiful (and marketable) outdoor furniture in a public access woodworking shop. An executive from a regionally dominant capitalist enterprise that was downsizing as a prelude to closure discussed the financial assistance and training the company was providing to its soon-to-be-retrenched workers, allowing them to retrain in occupations in which they might become self-employed in the noncapitalist sector. A community worker spoke about the new connections being forged between those serving out community service orders, elderly and disabled people, kindergarten kids, and interested local residents at the Fig Tree Community Garden, where previously "marginalized" people volunteer their labor and have created such a productive environment that they are now starting to market their garden produce. ${ }^{23}$

What emerged from this event was ample evidence of the extent and variety of noncapitalist economic practices that are being enacted in communities and regions. A conversation was begun between regions that are often pitted against each other in the race for new opportunities for "mainstream" economic development. What was patently evident was that understandings of economic difference and even of noncapitalist enterprise do exist, but they are likely to be voiced in terms of community building and environmental sustainability - that is, as "non-economic" and therefore marginal to the "mainstream economy." The video conference created a space where a conversation about economic revaluation could take place and where community members could see themselves as economically innovative and politically powerful. 


\section{Speaking a language of economic difference}

In our projects we have actively encouraged ourselves and others to begin speaking a language of economic difference and thereby to cultivate an unconscious in which dreams, fantasies, and desires for noncapitalist forms of economic organization might take shape and circulate. In the Pioneer Valley we trained community researchers (CRs) to conduct interviews with friends and acquaintances who participated in the noncapitalist sectors of the diverse economy. The academic members of the research team were well acquainted with economic diversity and well versed in the class language briefly explicated above. But we wanted to listen to how other people made sense of their economic worlds and to engage in an inclusive, as well as an interactive, conversation.

Rather than introduce a language that was already developed, we created a set of one-page narratives (mini-case studies) drawn from the Valley that illustrated the range of economic practices (including transactions, labor, and organizational forms - see figure 1.1) in a diverse economy. At the training we asked the community researchers to break into small groups to classify the narratives. What emerged when we reconvened, not surprisingly, were multiple and incomplete typologies. Ken Byrne (2000), who designed the exercise, notes that

these narratives were open to many different and possibly contradictory categorizations, opinions, judgments. For example, we included in the mix a firm that we saw as capitalist, but which had "green" or environmental concerns and for that reason might be attractive to some people. Consumer and producer co-operatives that were clearly part of a market economy were included. There was a communal enterprise (or worker collective). And we had stories of family and church-related activities which we ourselves had no consensus categorization for.

But it was the activity of categorization itself that "trained" the community researchers - trained them to see themselves as already active theorists of economic activity, conversant in one among many languages of economy (their own).

During the training a drawing of an iceberg was used to portray the economy, with the capitalist economy above the water line and the diverse, largely noncapitalist, community economy forming the huge submerged bulk below. We invited the CRs to collaborate with 
us in coming to know (and speak about) the dimly-lit economic realms below the surface of the water. And here the possibility that together we could construct a language and vision of economic difference in the Pioneer Valley became a motivating force. In their affirmative responses to our invitation, the CRs experienced and expressed desire, and we received a dose of energy and affirmation. It seemed that our language project was taking hold.

When the community researchers came back from interviewing their friends and other contacts about their daily activities, we held a debriefing retreat over a weekend. As one way to represent their findings we asked them to situate an activity from each of their interviews on a matrix taped to the wall (see figure 1.2). Predictably, the more than 50 examples were scattered around the matrix, and people were impressed by the diversity captured in this distribution. But then we gave them a set of red stickers and asked them to affix one to each activity they considered capitalist. To the amazement of everyone, only 4 of the 50 examples received stickers. This prompted a lively exploration of definitions of capitalism, as people began to distinguish capitalist from other market-oriented business activity. Over the course of the weekend, these types of exercises immersed us in a language of economic diversity, and began to elicit desires and fantasies about developing the noncapitalist sectors of the economy. ${ }^{24}$

An opportunity for more sustained practice in speaking a novel but shared economic language arose when a group comprising community and academic researchers, activists, and local NGO workers traveled from Massachusetts to Cape Breton, Nova Scotia to attend the Festival of Community Economics, which was a conference on worker co-operatives. Over the seven-day journey, including an 11-hour ferry ride, the group exchanged ideas, fears, hopes, and experiences of alternative economic practices. At the conference, we were immersed in the language of economic difference night and day - talking to co-operators from Quebec, other parts of North America, Mondragon and Valencia in Spain. On the way home, after four days of total immersion, the group began to fantasize about forming coops, dreaming up wild mixtures of activities that might be combined in a co-operative venture. We also talked about what alternatives to co-operatives there might be as ways of organizing activities in the community economy. After this experience the academic research team renamed itself the Community Economies Collective and invited our Australian colleagues, Kathie Gibson and Jenny Cameron, to join (Community Economies Collective 2001). 


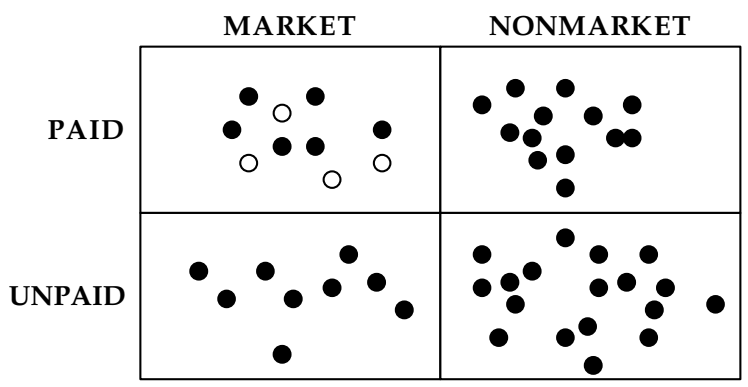

Figure 1.2 Distribution of examples from the community researchers' interview (blank dots represent capitalism)

\section{Inhabiting new economic identities}

One of our projects has been located in a resource region - the Latrobe Valley - that has experienced massive downsizing of the workforce as part of a process of privatization and restructuring (Gibson 2001). The formerly protected regional economy was opened up to international forces via the sale to global energy corporations of stateowned power stations and mines. In the absence of employment by the State Electricity Commission (SEC), many men have lost the sense of mastery they gained through involvement in a heavy industry producing the state's primary energy source, along with the accompanying sense of submission to their one-time employer - a paternalist monopoly Statutory Authority. The subject position of "worker" has been replaced by that of "unemployed person," and the repetitive practice of turning up to work has been replaced by the forced fortnightly call at Centrelink, the government unemployment office.

While the cessation of subjection to the SEC has created a potential opportunity for subjects to find alternative economic identities, many ongoing ritual practices recall the lost identity of worker: football matches on the weekend; attendance at football club or other working-men's clubs for regular social interaction; other sporting activities; union meetings; drinking with mates; and the daily performance of manhood - driving, dressing, acting, speaking a certain way, hanging out at home, mowing the lawn, and doing the car maintenance and other outdoor jobs. These activities are seen as "non-economic" and the subject positions they establish (as sports team supporters, drinking mates, club members, husbands, tinkerers) are seen as cultural, social, and domestic adjuncts to the ghost "worker" subject position. 
In the Community Partnering Project we attempted to shift this representation and to see the existing activities in which many people are involved as occupying a position of value within the diverse economy. The football club, the pub, the household, and the yard are all sites in which noncapitalist (and sometimes alternative capitalist) activities are practiced. Our challenge was to assist people to recognize alternative economic subject positions and to identify with them, to help create rituals, practices, and communities that could hail men and women into these alternative identities and unleash the powers of subjection that they might then assume.

After a number of community conferences and "how-to" workshops, some working groups were formed to foster the development of new economic and social initiatives - a community garden, a community tool shed, a youth circus skills training enterprise, and a creative reuse center (Santa's Workshop). These working groups involve a wide range of Valley residents, including retrenched SEC workers, unemployed young people, housewives, high school dropouts, people on disability pensions, single mothers, and people from non-English speaking backgrounds. Recruitment to these groups has not been through the intellectual project of re-presenting the regional economy but through face-to-face individual conversations with community researchers and through attending food-based events and community workshops. In many cases, the attractions of pleasure, fun, and working with others in an environment of value have drawn people to projects they were previously uninterested in or unaware of.

Take the story of Ken, who was retrenched at the age of 54 after 30 years as an electricity worker in the Valley:

Kathie: It must have been a big thing to stop formal work.

Ken: It was a big step.

Kathie: So did you look for work?

Ken: Oh yeah, I used to go round and go down to CES (Commonwealth Employment Service) and all that sort of stuff. I thought I was flogging a dead horse, in all honesty, 'cause nobody wants you at that age. And I don't have a trade. I was never an electrician or fitter or plumber or painter or anything like that - I didn't have a trade.

Just as he might have done in an interview at the CES, Ken reiterates his lack of qualifications and seeming unsuitability for employment. Ken, however, has many skills that he has taught himself. He is a concreter, furniture restorer, cabinetmaker, gardener, and builder. In addition, he is an avid model steam-train builder and a member of 
two local railway clubs for which he regularly performs voluntary work as a concreter and model train driver.

Since leaving the SEC Ken has become well known for his house decorations at Christmas-time - large painted wooden pictures lit up and mounted all over the roof. His example has inspired other neighbors to decorate their houses, producing the largest concentration of decorations in the Valley. As one of the working group projects, it was suggested that a community access "Santa's workshop" be set up in a disused pre-school as a site where people could create their own Christmas decorations using materials (sheets of plywood, paint, tools) donated from local businesses under the tutelage of Ken and a community researcher attached to the project (another ex-SEC worker):

Ken: They wanted somebody to show people, to sort of guide them on - those that were interested in decorating their house as such - in the right direction.... So we got started on it and had one woman the first day.... and then it gradually came until we had seventeen one day.... So [for] four weeks, two days [a week]. See, it wasn't bad. And we produced quite a bit of stuff, plus we did those decorations for Advance Morwell [the town's local business association] for their Christmas trees...

Kathie: What sorts of things did you observe?

Ken: The help they gave each other was very good. Everyone seemed to get on fairly well...everyone got on well. The kids that were there were not a problem.... I suppose the biggest thing ... was that nobody would clean up after themselves, not everybody, but there were some that didn't, they wouldn't clean the brushes properly and this sort of stuff. But overall it was great. And the core of people that came all the time and ended up on the last day to clean up and everything...they got on well.

Kathie: So had you ever seen yourself in the role of a teacher?

Ken: No. Not really.

Kathie: Did you enjoy it?

Ken: Oh yeah, it was quite good.

After the first year of operation, a core group of participants came forward to volunteer to run the workshop again in 2000. This time the workshop assisted local people to make their own decorations and also undertook to make decorations for local businesses and community organizations, in return for donations of timber and 
materials that could be put back into the pool for community use. Thus far, the enterprise operates outside of formal market relations, drawing upon voluntary labor, barter exchange with local business, payments in kind, and donations.

Through the experience with Santa's Workshop, Ken has gained a new economic identity within the community economy. His work has been recognized as suitable for the "work for the dole" payment from the state and he is now able to get a higher unemployment benefit. The group has been so successful that in 2001 they started nine months before Christmas in order to be able to cover the orders they had received, while a subset of the workshop group is looking into setting up a permanent Creative Reuse Center on the site. This would collect together industry wastes that can be recycled for craft and educational projects to be sold to schools, organizations, and individuals at low cost.

Santa's Workshop has been more than a place to learn to make Christmas decorations. It has been a site where new relations of community and communality have been engendered. Ken has found himself faced with difficult challenges - people copying his designs, others not cleaning up, the difficulty of accepting strangers, and of working mainly with women who lack skills as well as confidence. He and others have risen to the challenge of accepting and working with difference, creating in the process new ways of "being together" and cultivating forms of community that are not based upon narrow town parochialism but broader Valley identification. ${ }^{25}$

Kathie: So did you see people you wouldn't normally see working together? Were you surprised by the connections?

Ken: Yeah, probably. There was one woman there who [had a case of] insanity bordering on genius... and she had a few whinges... but she got on quite well with everyone.

Kathie: Did you go and look at each other's decorations?

Ken: Oh yeah, the local ones. Chris and Diane's were up till a week ago. [The interview was conducted mid-year.]

Kathie: Did you know these people before?

Ken: No. Didn't know any of them.

Kathie: So now you know more people?

Ken: Yeah. Well, that's what I thought the whole thing was for Morwell East people, that's the impression I got from [the councilor who first approached him]... and then it extended. But you couldn't just have an area, you've got to go to the whole Valley. 


\section{Conclusion: Multiplying Visions of Power, Community, and Politics}

It might appear that we have adopted a strange and misguided strategy in this chapter on economic politics outside the binary frame. Having recognized the forceful critiques of a localist political orientation, and having been sufficiently affected by our detractors to ruminate upon their comments here, we proceed to offer up more of the same - examples from our own research projects of small and local interventions. It is as though we were into homeopathy as a political strategy: if globalization discourse has produced weak and sickly locals, we will treat these symptoms by creating small, barely profitable enterprises, offering visions of communities that survive on gifts and voluntary labor, and telling stories of depressed regions where people cluster to make artifacts in community workshops. How can such activities provide an antidote to capitalist globalization?

There are many sets of answers to that question. One set focuses upon power, how it is conceptualized and worked with and against. Another set focuses upon community, and how we enact difference and belonging. Both these sets of answers bring us back to politics, what it is or might become.

But first to power. Theorists such as Hardt and Negri, or Harvey, Smith, and Swyngedouw, are not alone in seeing globally marshaled power as the only way to challenge globalization. Here they are influenced by a long tradition of modernist political thinking, and specifically that developed in the socialist tradition. Oppositional strength is gained through convening the masses - breaking down spatial barriers, overcoming single-issue fragmentation, creating identification with one liberatory cause, meeting might with might. ${ }^{26}$ Separateness, disarray, ambivalence, personalized actions, limited horizons, and local loyalties all signal a diminution of power in the face of the enemy. In the light of this vision, local initiatives such as those we have outlined are embarrassingly inadequate and definitely uncompelling.

Our response is to see this traditional left vision of power as but one among many. In its association with mass, domination, expansiveness, conflict, and singularity of identity, it can be seen as a masculinist and objectivist conception. The theorist seems immune to power - he can remain separate enough to analyze and strategize against it, even to counter it by mastering its tools. Alongside this conception we are eager to allow for other forms of power to be 
recognized and fostered. ${ }^{27}$ We are taken, for example, with the constitutive power of small and local processes that are found the world over - photosynthesis, for example, or household provisioning. These processes that inhabit the entire natural and social landscape are powerfully involved in constituting creatures and subjects. In feminism we see a political project (and process of power) that covers the globe in a similarly constitutive way.

When globalization is consolidated into an all-encompassing, dominant formation against which opposition must be globally arrayed, it is consolidated in the name of the capitalist economy. The conduits of global capitalist power take the form of "the" market, the global finance sector, and transnational corporations. What happens when we begin to doubt the identity of the economy as singularly capitalist? The frame in which globalization makes sense as a single economic process disappears. The concept of a diverse economy calls forth a vision of an immensely variegated noncapitalist economic landscape which is no less global in extent than is capitalism. Its conduits of global power are many different market and nonmarket exchanges, forms of enterprise, and livelihoods. But this global power is not consolidated, concentrated, distilled, mobilized, and conflictual: it is diffuse, partial, constitutive, and sustaining.

The constitutive nature of power brings us to the power of subjection and its role in our thinking beyond the global/local binary. The judgment that size and extensiveness are coincident with power is not simply a rational calculation in our view but also a discursive choice and emotional commitment. We are interested in interrogating the investment we might have as researchers in seeing our bodies taken over by the "power" of globalization, submitting to its superior sway, and relishing our privileged insight into its workings. No such thrill immediately follows from telling stories of local becoming. Yet new emotions do get produced. In the practice of local engagements "nonrational" states can be fostered, ones that create receptivity to alternative discourses of power and economy. Our strategy for confronting globalization is thus not merely representational. It also involves novel practices, differently subjected bodies, and techniques for cultivating the capacities of local subjects - as agents rather than victims in a diverse economy (Gibson-Graham 2003).

A second worrying aspect of our work, for some, is our willingness to use a language of community. How can we invoke community in the light of contemporary repressive and defensive connotations and practices of communities (whether we think of the cloying cheeriness of community development or the ruthless violence of ethnic cleansing)? Hardt and Negri's recent attack upon place-based 
movements voices the deep suspicion of community that many progressives harbor. Are we not just falling into the same sticky set of associations by working with people in place on a project called "Community Economies"? Will not these attempts at (re)vitalizing local economic visions simply participate in constructing communities of sameness whose potential successes will be gained at the expense of others, both without and within ${ }^{28}$

Again our response is that this vision contains but one model of community. Communities can be constituted around difference, across places, with openness to otherness as a central ethic (Lingis 1994). Surely the project of constituting communities of tolerance and peaceful diversity cannot be shunned at this conjuncture. And the locality is one place to begin such a project. New forms of community are to be constructed through cultivating the communal capacities of individuals and groups and, even more importantly, cultivating the self as a communal subject. We have attempted to do this in our action research projects, as well as in our own social locations in the academy. Alongside community researchers we are speaking a new language of economy, listening to others, articulating and amplifying each other's thoughts, creating and sharing novel desires and fantasies. Our micropolitical cultivations involve food, parties, pleasurable outings, and just hanging out - we have come to see how important these are to the creation of new receptivities and to untying the knots of fear that stand in the way of self-transformation. For us, then, the process of constructing communities of difference feels like an unfamiliar and radically fresh form of politics, rather than a recourse to parochialism and small-scale manageability (with all the inconsequence and marginality that implies).

Finally, what can we say about an economic politics outside the binary frame? In the face of the programs and plans of antiglobalization theorists and political analysts, our micropolitical experiments can easily be dismissed. Most analysts, like Hardt and Negri (2000: 411 ), offer a vision of an appropriate political response to globalization that is very distant from the one we are pursuing:

Imperial corruption is already undermined by the productivity of bodies, by co-operation, and by the multitude's designs on productivity. The only event that we are still awaiting is the construction, or rather the insurgence, of a powerful organization. The genetic chain is formed and established in ontology, the scaffolding is continuously constructed and renewed by the new co-operative productivity, and thus we await only the maturation of the political development of the posse. We do not have any models to offer this event. Only the 
multitude through its practical experimentation will offer models and determine when and how the possible becomes real.

We are no longer capable of waiting for the multitude to construct a powerful organization (Gibson-Graham 1996). Instead, we continue to be inspired by feminism as a global force, one that started small and personal and largely stayed that way, that worked on cultivating new ways of being, that created new languages, discourses, and representations, that built organizations, and that quickly (albeit unevenly) encompassed the globe.

Globalization appears to call for one form of politics - mobilization and resistance on the global scale. But we believe there are other ways of practicing transformative politics - involving an opening to the local as a place of political creativity and innovation. To advocate local enactments is in no way to suggest that other avenues should close down. We would hope for the acceptance of multiple powers and forms of politics, with an eye to increasing freedoms and not limiting options. Rather than equivocating, with paradoxical certainty, about when and how a challenge to globalization will arise (the Hardt and Negri position), we have engaged in a here-and-now political experiment - working on ourselves and in our backyards. ${ }^{29}$ This is not because we think that we have found the only way forward, but because we have become unable to wait for an effective politics to be convened on some future terrain.

The form of politics we are pursuing is not transmitted via a mass organization, but through a language and a set of practices. A language can become universal without being universalist. It can share the space of power with other languages, without having to eradicate or "overthrow" them. ${ }^{30}$ Academic, NGO, and internet networks can become part of a system of transmission, translation, amplification. In our (admittedly hopeful) vision, the language of the diverse economy and accompanying practices of noncapitalist development may have global purchase one day.

Speak now and hasten the future.

\section{ACKNOWLEDGMENTS}

We would like to thank Andy Herod, Paul Plummer, and Melissa Wright for inviting us to present an early version of this paper as the keynote to their conference on "Theorizing Space and Time at the End of the Millennium," which was held at the University of Georgia in April of 1999. Andy and 
Melissa have since been extraordinarily patient with us as we nearly endlessly deferred completion of the final draft. In addition, all the research and much of the thinking for the paper took place in the context of a larger collectivity - the Community Economies Collective involving Brian Bannon, Carole Biewener, Jeff Boulet, Ken Byrne, Jenny Cameron, Gabriela Delgadillo, Rebecca Forest, Stephen Healy, Greg Horvath, Beth Rennekamp, AnnaMarie Russo, Sarah Stookey, Anasuya Weil, and ourselves.

\section{NOTES}

1 Not to all others, actually. An equally senior and well-known political theorist expressed his excitement about the presentation and then, turning to the audience, asked benignly but forcefully: "What's the matter with you people?" This did our hearts good, as you might imagine.

2 Dirlik (1999: 5) puts it thus: "While the local derives its meaning from the global, the spatial itself derives its meaning from a parallel with globality, and stands in the same oppositional relationship to the place-based as the global does to the local." It must be noted that others resist the association of space with the global alone. Massey (1999: 280), for example, prefers to imagine the spatial as much more than the abstracted spread and differentiation of "stories of progress, of development, of modernization." Her theory of space/spatiality opens up the possibility of "the existence of multiplicity," "disruption," and "the potential openness of the future" (279-85), and represents an alternative political and epistemological framing of the binary (one with which we are very much in sympathy).

3 It is helpful to interrogate what exactly is meant by "power" in this context. John Allen (1999) has provided a useful summary of the theories of power currently being drawn upon by geographers and others. Of interest in the context of this chapter is his focus upon the different "spatial vocabularies of power" associated with each conception. He distinguishes between (1) the Weberian and Marxian view that sees power as centered, as an already distributed capability that is "owned" by certain individuals, groups, or institutions; (2) the view of power associated with Giddens and Mann that sees it as a medium, something that is generated as individuals, groups, or organizations "mobilize" social interactions and transmit their power through networks that are more or less "stretched" over space; and (3) the Foucauldian view of power as site-specific practices that are constitutive of subjects. He further distinguishes between instrumental modes of power that enforce power "over others" from associational modes of power that work with others to "empower." Throughout this chapter we will refer to Allen's summary as a way of exploring how different conceptions of power inflect views about the global/local binary. 
4 Here they are drawing upon a vision of power as the capability of mobilizing resources over space through distanciated networks. Allen (1999: 199-200) associates this view with the work of Giddens and Mann.

5 Unless it can form the base from which to mobilize capabilities and upscale to the degree of spatial reach and scope possessed by global organizations.

6 Michael Watts's (1999: 90-2) criticism of the hopeful emphasis placed by post-development theorists and activists upon social movements, the "local community," and "grassroots initiatives" foreshadows, and to some extent mirrors, the views of Hardt and Negri. Watts is uncomfortable with the "constant uncritical appeal to the local, to place and to the cultural (where cultural is synonymous with a self-consciously local sense of community)" by proponents of "poststructural approaches to development." Pointing to the violent localism of Hindu fascism, rather than the more benign localism of Andean Indian co-operatives, Watts warns of the "potentially deeply conservative, and occasionally reactionary, aspects of such local particularisms." What is fascinating about the similarities between the arguments of Watts and Hardt and Negri is the extent to which a heightened "sensitivity" to the conservatism of the local appears to be directly correlated with an emboldened faith in the progressiveness of the global.

7 Massey's (1999: 284) restatement of what the spatial imaginary might be "outside" of the place (local)/space (global) binary also emphasizes openness to unknown futures.

8 Though we want to be clear that we see ourselves as working within/ alongside his project, rather than against it.

9 This is a curious comment, given that "development" is now widely recognized as a "local" project of particular Western economies and regions that very successfully became globalized (Gibson-Graham 2003). Think of the ways that models of development have been generalized from the specific industrial pathways that arose in certain places (the north of England in the nineteenth century or the Third Italy in the late twentieth century). These local stories have been transformed into generic models that have been imposed worldwide (for a comparison with models of urban development and "global" cities, see McCann, this volume). Can Dirlik be blind to this history? Unlikely. What force is at large, then, that produces such analytical occlusion?

10 Activist Kevin Danaher (2001: 12) writes:

Grassroots globalisation comprises many large and growing movements: the fair trade movement, micro-enterprise lending networks, the movement for social and ecological labelling, sister cities and sister schools, citizen diplomacy, trade union solidarity across borders, worker-owned co-ops, international family farm networks, and many others. While these constituents of grassroots globalisation lack the money and government influence possessed by the 
corporations, they showed at the WTO protests in Seattle that they are able to mobilise enough people to halt the corporate agenda in its tracks, at least temporarily.

11 Indeed, in his criticisms of the potentially regressive function of "nonconfrontational" kinds of resistance advocated by postcolonial writers, Dirlik (1999: 43n, insert ours) echoes the line that Hardt and Negri take against theorists of hybridity: "One might suggest, in the present context, that nonconfrontational resistance, which may in fact be quite functional to systemic [capitalist/Empire] health, is about the most logical kind of resistance permitted under conditions of "hybridity."'

12 We cannot assume that because something is local and unique it is not globally consequential. Indeed, it may be extremely powerful, given the impossibility of restricting its meaning or emotional resonance to any particular location.

13 Indeed, the experience of being a woman is still being transformed, although "feminism" seems to many to have waned.

14 Capitalocentrism is the propensity to understand noncapitalist economic activities as either the same as, a complement to, the opposite of, or contained within, capitalism.

15 Clearly, in Allen's terms we are taking off from Foucault's conception of power, by first turning to look at the subjects already created by globalization discourse (including ourselves) and then beginning to think about constituting subjects empowered by different discourses. Allen (1999: 204) highlights the "microlevel" focus of Foucault's theory, seeing this as a restriction that prevents analysis of "power as a form of distanciated 'government."' We, like Foucault, are not concerned to dispute the existence of "distanciated government" but, rather, to highlight the (concomitant and potentially counter) power of local practices of subject formation.

16 Though they may be viable and sustainable.

17 Social capital theory, which is currently enjoying a surge of interest among policy makers looking for a "third way," recognizes the importance of these social relations, networks, and non-market economic transactions, but only as preconditions (or co-conditions) for a healthy capitalism. We are interested in foregrounding many of the activities included as "social capital" but within a diverse economy of non-essentialized identities and nondeterministic dynamics.

18 The Mondragon Co-operative Corporation is a particularly inspirational example of a local experiment that operates on a global imaginative and emotional scale. The co-operative enterprises that comprise the MCC have been a catalyst of optimism and action around the world, and the cooperators who are at its heart are involved in a form of economic politics beyond the global/local binary frame. In the surplus produced through the communal class processes of the Mondragon intentional economy, cooperators have marshaled a huge potentiating force - the ability through surplus distribution to create more co-ops and a sustainable community 
in the Basque region. Their high-tech commodities are sold on global markets and they have upscaled into supermarket retailing. However, rather than installing and signifying capitalism, these practices have allowed noncapitalist class processes to develop and thrive. Many visitors interested in co-operatives and worker self-management have visited Mondragon on study tours and the corporation is committed to publicizing its successes throughout the world.

19 For example, students at the local university finance their studies by working in the co-operative electronics component factory that is part of the university. Along with their formal studies, students gain experience in co-operative work practices and principles.

20 Hasana Sharp's discussion of the Althusserian concepts of overdetermination and underdetermination has helped us situate our "action research" methodology closer to the post-structuralist project of "becoming," dissociating it somewhat from its origins in the more traditional modernist project of "emancipation" (Laclau 1993). Articulating the notion of underdetermination, Sharp (2000: 32-3) writes:

In emphasizing the unevenness of contradiction in social formations, and the way in which one social force can never be reduced to the hollow effect of another, there remains not only the various positive forces acting upon relations, subjectivities, and institutions, but the undeveloped and unforeseeable determinations which inevitably characterize material encounters. As opaque as this may sound, this opacity is precisely what Althusser, in his few somewhat cryptic remarks about underdetermination, challenges us to think: the unanticipated nature of beginnings, the possible, what will become, the unpredictable effects of encounters.

21 Here we have been inspired by William Connolly's (1999) work on micropolitics (see Gibson-Graham 2003).

22 All of the examples discussed in the remainder of this chapter emerge from a number of funded research projects. The US material was generated as part of National Science Foundation Grant no. BCS-9819138 by co-researchers Brian Bannon, Carole Biewener, Jeff Boulet, Ken Byrne, Gabriela Delgadillo, Rebecca Forest, Julie Graham, Stephen Healy, Greg Horvath, Beth Rennekamp, AnnaMarie Russo, Sarah Stookey, and Anasuya Weil. A narrative of the US project can be found in Community Economies Collective (2001). The Australian material emerged from the Australian Research Council Large Grant "Economic citizenship and regional futures" and the Australian Research Council/Strategic Partnerships with Industry and Training Grant "Building sustainable regions: Testing new models of community and council partnership" conducted by Jenny Cameron and Katherine Gibson.

23 A selection of the projects showcased has been written up as entries on the Community Economies website (www.communityeconomies.org/ stories), another product of our action research projects. 
24 AnnaMarie, a planner and academic member of the research team, began imagining how people involved in household economic activities, networks of mutual care, and volunteer labor might be engaged in formal conversations with economic development planners about directing resources toward enhancing neighborhood support systems that already sustain the community, rather than toward businesses that might not benefit local residents or might contribute to their displacement.

25 The old preschool site that housed Santa's Workshop has become a new kind of public space where organizational, ethical, and identity issues are negotiated by people working alongside each other in a communal environment. In Allen's (1999: 209-12) terms we could see this process as involving the practice of "associational power, or power with others," an enabling rather than dominating form of power.

26 As we noted above, this view of power is to some extent shared by theorists like Dirlik and Escobar, who look to a wide range of social movements and forms of grassroots globalization to produce resistance on a global scale. It is important to note that we fully support these movements and forms of mobilization. At the same time we are interested in making a space for additional forms of politics.

27 And here we agree with Allen's (1999: 213) concluding comments:

There are many possibilities for exercising power with rather than over others, not all of which entail different sets of relations from those routinely described in terms of instrumental power. As yet, however, the language of power over others has a stronger hold on our spatial imaginations than that of empowerment and enablement or the entanglement of its many different forms.

28 Other critiques take a different tack and insinuate that our project initiatives, by shoring up communities that capital and the state have abandoned, are conspiring with the reactionary trend toward divestiture of public resources and abrogation of public rights, treating families and communities as newly responsible for their own welfare.

29 At another conference where we gave the keynote and which the organizers had billed as an exercise in "rethinking" left approaches, we were seen quite literally as confined to the backyard. Immediately following the plenary, our presentation on the local politics of the diverse economy was excoriated by four male discussants who categorized it as "Hills hoist socialism." (The Hills hoist, a four-sided outdoor clothes line, is an icon of Australian suburbia, a local invention that until quite recently graced the backyards of almost every quarter-acre lot and spoke of domesticity, order, and the Aussie dream of homeownership.) Hills hoist socialism, it seems, was associated with the cultural left who saw the challenging of daily practices as just as revolutionary as any other form of politics. For this resolutely left (and male) audience, our local, 
face-to-face politics was clearly wrong-headed and probably overly feminized.

30 Here again feminism comes to mind.

\section{REFERENCES}

Allen, J. 1999: Spatial assemblages of power: From domination to empowerment. In D. Massey, J. Allen, and P. Sarre (eds.), Human Geography Today. Cambridge: Polity Press, 194-218.

Altvater, E. 1993: The Future of the Market. London: Verso.

Butler, J. 1997: The Psychic Life of Power. Stanford, CA: Stanford University Press.

Byrne, K. 2000: Personal communication with Ken Byrne, Center for International Education, University of Massachusetts at Amherst.

Callon, M. 1998: Introduction: The embeddedness of economic markets in economics. In M. Callon (ed.), The Laws of the Markets. Oxford: Blackwell, $1-57$.

Community Economies Collective 2001: Imagining and enacting noncapitalist futures, Socialist Review, 28 (3 and 4), 93-135.

Connolly, W. 1999: Why I Am Not a Secularist. Minneapolis: University of Minnesota Press.

Danaher, K. 2001: More power to the people, Guardian Weekly, May 3-9: 12.

Dirlik, A. 1999: Place-based imagination: Globalism and the politics of place. Unpublished manuscript, Department of History, Duke University, Durham, NC.

Escobar, A. 2001: Culture sits in places: Reflections on globalism and subaltern strategies of globalization, Political Geography, 20, 139-74.

Foucault, M. 1984: On the genealogy of ethics: An overview of work in progress. In P. Rabinow (ed.), The Foucault Reader. New York: Pantheon, $340-72$.

Gibson, K. 2001: Regional subjection and becoming. Environment and Planning D: Society and Space, 19 (6), 639-67.

Gibson, K., Cameron, J., and Veno, A. 1999: Negotiating restructuring: A study of regional communities experiencing rapid social and economic change. Australia Housing and Urban Research Institute (AHURI), Working Paper No. 11. Melbourne: AHURI, http://www.ahuri.edu.au

Gibson-Graham, J. K. 1994: "Stuffed if I know": Reflections on postmodern feminist social research. Gender, Place and Culture, 1 (2), 205-24.

Gibson-Graham, J. K. 1996: The End of Capitalism (As We Knew It): A Feminist Critique of Political Economy. Cambridge, MA: Blackwell.

Gibson-Graham, J. K. 1999a: Beyond global versus local: Economic politics outside the binary frame. Paper presented at the conference on "Theorizing space and time at the end of the millennium," University of Georgia, Athens, April 9-11. 
Gibson-Graham, J. K. 1999b: Capitalism goes the "Full Monty." Rethinking Marxism, 11 (2), 62-6.

Gibson-Graham, J. K. 2000: Poststructural interventions. In E. Sheppard and T. Barnes (eds.), A Companion to Economic Geography. Cambridge, MA: Blackwell, 95-110.

Gibson-Graham, J. K. 2003: An ethics of the local. Rethinking Marxism, 15 (1).

Gibson-Graham, J. K., Resnick, S., and Wolff, R. (eds.) 2001: Re/Presenting Class: Essays in Postmodern Marxism. Durham, NC: Duke University Press.

Gibson-Graham, J. K., Resnick, S., and Wolff, R. (eds.) 2000: Class and Its Others. Minneapolis: University of Minnesota Press.

Graham, J. 1992: Anti-essentialism and overdetermination - A response to Dick Peet. Antipode, 24 (2), 141-56.

Hardt, M. and Negri, A. 2000: Empire. Cambridge, MA: Harvard University Press.

Harvey, D. and Swyngedouw, E. 1993: Industrial restructuring, community disempowerment and grass roots resistance. In T. Hayter and D. Harvey (eds.), The City and the Factory. London: Mansell, 11-26.

Laclau, E. 1996: Emancipation(s). London: Verso.

Latour, B. 1993: We Have Never Been Modern (trans. C. Porter). Cambridge, MA: Harvard University Press.

Lingis, A. 1994: The Community of Those Who Have Nothing in Common. Bloomington and Indianapolis: Indiana University Press.

Marcus, S. 1992: Fighting bodies, fighting words: A theory and politics of rape prevention. In J. Butler and J. Scott (eds.), Feminists Theorize the Political. London: Routledge, 385-403.

Massey, D. 1994: Space, Place, and Gender. Minneapolis: University of Minnesota Press.

Massey, D. 1999: Spaces of politics. In D. Massey, J. Allen, and P. Sarre (eds.), Human Geography Today. Cambridge: Polity Press, 279-94.

Sharp, H. 2000: Is it simple to be a feminist in philosophy?: Althusser and feminist theoretical practice. Rethinking Marxism, 12 (2), 18-43.

Smith, N. 1993: Homeless/global: Scaling places. In J. Bird, B. Curtis, T. Putnam, G. Robertson, and L. Tickner (eds.), Mapping the Futures: Local Cultures, Global Change. London: Routledge, 87-119.

Swyngedouw, E. 1997: Excluding the other: The production of scale and scaled politics. In R. Lee and J. Wills (eds.), Geographies of Economies. London: Edward Arnold, 167-76.

Watts, M. 1999: Collective wish images: Geographical imaginaries and the crisis of national development. In D. Massey, J. Allen, and P. Sarre (eds.), Human Geography Today. Cambridge: Polity Press, 85-107. 